\title{
U-Pb dating by zircon dissolution method using chemical abrasion
}

\author{
LUCY TAKEHARA ${ }^{1}$, FARID CHEMALE JÚNIOR ${ }^{2}$, LÉO A. HARTMANN ${ }^{3}$, \\ IVO A. DUSSIN ${ }^{4}$ AND KOJI KAWASHITA ${ }^{4}$ \\ ${ }^{1}$ Serviço Geológico do Brasil - CPRM, SGAN 603, Conjunto “J”. Parte A, $1^{\circ}$ andar, 70830-030, Brasília, DF, Brasil \\ ${ }^{2}$ Laboratório de Geocronologia, Instituto de Geociências, Universidade de Brasília, \\ Campus Darcy Ribeiro, s/n, 70904-970, Brasília, DF, Brasil \\ ${ }^{3}$ Instituto de Geociências, Universidade Federal do Rio Grande do Sul, \\ Av. Bento Gonçalves, 9500, Bairro Agronomia, 91501-970, Porto Alegre, RS, Brasil \\ ${ }^{4}$ Centro de Pesquisa Geocronológicas, Universidade de São Paulo, \\ Rua do Lago, 562, 05508-080, São Paulo, SP, Brasil
}

Manuscript received on February 18, 2010; accepted for publication on August 24, 2011

\begin{abstract}
Chemical abrasion was carried out on zircons grains of the Temora II standard for U-Pb dating prior to analyses using in situ Laser Ablation-MultiCollector Ion Coupled Plasma Mass Spectrometer (LA-ICPMS) followed by the Isotope Dissolution Thermal Ionization Mass Spectrometer (ID-TIMS) method. The proposed methodology was herein applied in order to reduce primarily the effects of secondary $\mathrm{Pb}$ loss, the presence of common lead and/or silicate impurities. Nine Temora II zircon grains were analyzed by the laser ablation method yielding an age of $418.3 \pm 4.3 \mathrm{Ma}$. Zircon grains of a same population were separated for chemical abrasion before dissolution and mass spectrometry analyses. Six fractions of them were separated for isotope dissolution using ${ }^{235} \mathrm{U}_{-}^{205} \mathrm{~Pb}$ mixed spike after we have checked and assured the laboratory conditions of low blank values for total $\mathrm{Pb}$ of less than $2 \mathrm{pg} / \mathrm{g}$. The obtained U-Pb zircon age by the ID-TIMS method was $415.7 \pm 1.8 \mathrm{Ma}$ (error $0.43 \%$ ) based on four successful determinations. The results are consistent with the published ages for the Temora diorite (Temora I - 416.75 $\pm 1.3 \mathrm{Ma}$; Temora II $-416.78 \pm 0.33 \mathrm{Ma}$ ) and established as $416 \pm 0.33 \mathrm{Ma}$. The technique is thus recommended for high precision U-Pb zircon analyses (error $<1 \%$ ), mainly for high resolution stratigraphic studies of Phanerozoic sequences.
\end{abstract}

Key words: chemical abrasion, ID-TIMS, LA-MC-ICPMS, U-Pb dating, zircon dissolution.

\section{INTRODUCTION}

The age determinations of geological events are a significant tool in basic and applied earth science studies. In the last two decades, the in situ, high resolution $\mathrm{U}-\mathrm{Pb}$ dating by SHRIMP (Sensitive High Resolution Ion Microprobe) (Williams 1998,

Correspondence to: Lucy Takehara

E-mail: lucytakehara@gmail.com.br
Rasmussen 2005) and LA-ICPMS (Laser Ablation Ion Coupled Plasma Mass Spectrometer) (Kosler et al. 2001, Jackson et al. 2004, Pickhardt et al. 2005) has brought new insights into the understanding of crystallization ages of minerals, especially zircon. The complexity of geological processes registered in the minerals can be dated with these techniques. These solid state, in situ determinations are useful 
to geoscientists because they can identify the timing of events such as rock generation, metamorphism and deformation in the crust and mantle.

Despite the great advance in U-Pb in situ dating with SHRIMP and LA-ICPMS methods, in some cases these techniques do not attain the required accuracy to date geologic events that occurred at the end of the Precambrian and in the beginning of the Phanerozoic. In these cases, more precise techniques are required, such as the isotopic dissolution (ID) methods in minerals using Thermal Ionization Mass Spectrometer (IDTIMS). However, the total $\mathrm{Pb}$ blank (common $\mathrm{Pb}$ contamination) in the laboratory has to be less than $2 \mathrm{pg} / \mathrm{g}$. Indeed, in good laboratory conditions the dating of one crystal or part of it by ID-TIMS may yield better precision than $0.1 \%$ of error, while the in situ dating with $25 \mu \mathrm{m}$ beam gives $1 \%$ or more of error (Bowring and Schmitz 2003).

The chemical abrasion procedure in the zircon dissolution method is widely used because it may avoid the common $\mathrm{Pb}$ that is present in the external surface of the crystal. This procedure has improved the high resolution $\mathrm{U}-\mathrm{Pb}$ dating.

Thus, the aim of this study is to present the $\mathrm{U}-\mathrm{Pb}$ dating of zircons of the Temora diorite by IDTIMS by applying the chemical abrasion technique to the analyzed zircon fractions before the isotope dissolution. The sample for this study was provided by the Australian Geological Survey Organization, and the diorite has been systematically used as standard for geochronological studies (Black et al. 2003). In order to separate the zircon grains with a single crystallization phase (zircon with overgrowth), $\mathrm{U}-\mathrm{Pb}$ in situ dating by the LA-MC-ICP-MS method was carried out in the zircon concentrate.

\section{ANALYTICAL PROCEDURES}

After the crushing and milling of the diorite Temora II sample, zircon grains were separated by conventional procedures using heavy liquids and magnetic separator after concentration by hand panning. The most clear and inclusion-free zircon grains from the least magnetic fractions were handpicked for in situ LA-MC-ICP-MS analyses and exposed to chemical abrasion for subsequent U-Pb ID-TIMS analyses.

\section{U-Pb in situ LA-MC-ICPMS ANALYSES}

All zircon grains were mounted in epoxy in $2.5-\mathrm{cm}-$ diameter circular grain mounts and polished to reveal the internal part of the grains. Images of zircons grains were obtained using binocular microscope Leica MZ $12_{5}$ and backscattering images with the scanning electron microscope Jeol JSM 5800. Zircon grains were dated with a New Wave UP213 laser ablation microprobe coupled to a Neptune MC-ICP-MS at the Isotope Geology Laboratory of Universidade Federal do Rio Grande do Sul (UFRGS). Isotope data were acquired using a static mode with the spot size of $25 \mu \mathrm{m}$. The Laser-induced elemental fractional and instrumental mass discrimination were corrected by the GJ-1 reference zircon (Simon et al. 2004), following the measurement of two GJ-1 analyses to every ten sample zircon spots. The external error was calculated after the propagation error of the GJ-1 mean and the individual sample zircon (or spot). Laser operating conditions are summarized in Table I, and a detailed description of analytical method can be found in Chemale Jr. et al. (in press)

TABLE I

Operation conditions of the Laser Ablation type New Wave UP213 and MC-ICP-MS Neptune

\begin{tabular}{|l|l|}
\hline Laser type New Wave UP213 & MC-ICP-MS Neptune \\
- Laser output power $6 \mathrm{~J} / \mathrm{cm} 2$ & - Cup configuration: \\
- Shot repetition rate $10 \mathrm{~Hz}$ & Faradays: ${ }^{206} \mathrm{~Pb},{ }^{208} \mathrm{~Pb},{ }^{232} \mathrm{Th},{ }^{238} \mathrm{U}$ \\
- LIC: ${ }^{202} \mathrm{Hg},{ }^{204} \mathrm{Hg}{ }^{204} \mathrm{~Pb},{ }^{207} \mathrm{~Pb}$ \\
& - Gas input: \\
& Coolant flow (Ar) $15 \mathrm{l} / \mathrm{min}$ \\
& Auxiliary flow (Ar) $0.81 / \mathrm{min}$ \\
& Carrier flow $0.751 / \mathrm{min}(\mathrm{Ar})$ \\
& $+0.451 / \mathrm{min}(\mathrm{He})$ \\
& - Acquisition $50 \mathrm{cycles}$ of $1.048 \mathrm{~s}$ \\
\hline
\end{tabular}


U-Pb ID-TIMS ANALYSES

\section{Water and acid preparation and washing}

In the Isotope Geology Laboratory of UFRGS clean laboratory facility (class 100), we obtained the best water and acid blanks for the $\mathrm{U}-\mathrm{Pb}$ isotope dilution method, taking into account the suggestions of the researchers of Earth Time group (Bowring, personal communication).

The study started by improving the laboratory conditions in order to get low $\mathrm{Pb}$ blanks for the analyses. This involved the purification of water to prepare the acids and the cleaning of the polytetrafluoretilene (PTFE) vials, bomb and microcapsules to dissolve the zircon grains. In order to get pure acids, we produced purified water below $2 \mathrm{pg} / \mathrm{g}$ of total $\mathrm{Pb}$, from initial Milli- ${ }^{\circledR}$ water with blank values lower than $10 \mathrm{pg} / \mathrm{g}$.

To purify the Milli- ${ }^{\circledR}$ water, we used two techniques: (i) filtering process with anionic resin (10 ml each time) and (ii) bi-destillation of Milli- $\mathrm{Q}^{\circledR}$ water. The second technique was more effective and faster, producing a larger amount of ultrapure water with a blank of total $\mathrm{Pb}$ under $2 \mathrm{pg} / \mathrm{g}$. After the preparation of water and acids with total $\mathrm{Pb}$ blank values (under $2 \mathrm{pg} / \mathrm{g}$ ), we proceeded to the cleaning procedure of microcapsules and bombs. Each bomb and microcapsule was washed nine (9) times with the following acids sequence: $\mathrm{HF}$ conc $+\mathrm{HNO}_{3} 7 \mathrm{~N}$ at $200^{\circ} \mathrm{C}$ in the oven for one day ( 3 times); $\mathrm{HCl} 6 \mathrm{~N}$ at $200^{\circ} \mathrm{C}$ in the oven for two days (3 times); and $\mathrm{HF}$ conc $+\mathrm{HNO}_{3} 7 \mathrm{~N}$ at $200^{\circ} \mathrm{C}$ in the oven for one day (3 times). In each acid washing exchange the bomb and microcapsules were washed three times with purified water with $2.5 \mathrm{~Pb} \mathrm{pg} / \mathrm{g}$ of total $\mathrm{Pb}$.

\section{Zircon pre-treatment (including chemical abrasion)}

Zircon crystals from the same igneous population analyzed at Isotope Geology Laboratory of UFRGS by LA-MC-ICP-MS were separated by handpicking for ID-TIMS analyses. These crystals were clear and inclusion free. All zircon crystals were photographed with a binocular microscope. The isotope analyses were done after the following preparation steps.

The zircon grains were pre-treated following the procedures suggested by Mundil et al. (2004), which are: annealing (thermal treatment at $850^{\circ} \mathrm{C}$ for $36 \mathrm{~h}$ ); making photograps of all crystals using the binocular microscope; chemical abrasion (HF conc in Teflon vials, as pressurized dissolution, at $200^{\circ} \mathrm{C}$ for $16 \mathrm{~h}$ ); washing several times with tridistilled $\mathrm{HNO}_{3}$; cleaning with aqua regia in an ultrasonic equipment followed by tridistilled $\mathrm{HNO}_{3}$; making photographs of all crystals using the binocular microscope to estimated the sample weight; zircons were separated into groups of 6 to 8 grains, weighing approximately $10 \mu \mathrm{g}$ each; and tgrouping the zircon grains that were then transferred to ultraclean microcapsules (PFTE Krogh type).

\section{Zircon dissolution and $\mathrm{U}-\mathrm{Pb}$ analyses}

After the chemical abrasion, the separated zircon grains were dissolved in a microcapsule as follows: 10 drops of ultraclean $\mathrm{HNO}_{3} 7 \mathrm{~N}$ were added and heated in the hot plate for 30 minutes at $100^{\circ} \mathrm{C}$; the zircon grains were washed three times with $\mathrm{HNO}_{3}$ $7 \mathrm{~N}$, and a drop of acid plus zircon grains was left in the bottom of the microcapsule; $200 \mu 1$ of $50 \%$ $\mathrm{HF}$ was added with $4 \mu 1$ double spike ${ }^{205} \mathrm{~Pb}^{233} \mathrm{U}^{235} \mathrm{U}$ (UNB205PC) in the individual microcapsule. Three sets of five microcapsules each were placed on an elevated rack in a $125 \mathrm{ml}$ digestion vessel, allowing the vapor transfer dissolution in a mixture with 50 $\% \mathrm{HF} / \mathrm{HNO}_{3}$ conc (30/1). The digestion vessel was placed in a metal jacket and left in an oven for six days at $220^{\circ} \mathrm{C}$. After the zircon dissolution, the sample + spike were transferred to Teflon ${ }^{\circledR}$ vials, which were dried with $20 \mu \mathrm{l}$ of $3 \mathrm{M} \mathrm{HCl}+5 \mu 10.25 \mathrm{M} \mathrm{H}_{3} \mathrm{PO}_{4}$. The dried dissolved zircon samples were loaded in rhenium filament with silica gel $+\mathrm{H}_{3} \mathrm{PO}_{4}$. The $\mathrm{U}$ and 
$\mathrm{Pb}$ concentrations were determined in a VG-Sector 54 mass spectrometer with Daly detector and ion counting system of ORTEC, in a single mode. $\mathrm{Pb}$ was analyzed as metal and $\mathrm{U}$ as oxide. The isotope masses of ${ }^{204} \mathrm{~Pb},{ }^{205} \mathrm{~Pb},{ }^{206} \mathrm{~Pb},{ }^{207} \mathrm{~Pb},{ }^{208} \mathrm{~Pb},{ }^{235} \mathrm{U}$ and ${ }^{238} \mathrm{U}$ were collected. Repeated analyses of NBS-981 and NBS-982 presented a $\mathrm{Pb}$ fractionation of $\leq 0.1$ $\%$ amu, similar to that of NBS 982 analyzed in the same turret and whose zircon samples were also analyzed. All data were reduced using the PBDAT program and Isoplot 3.1 (Ludwig 2003).

We dissolved seven zircon samples and two blanks. Two samples presented either very low ${ }^{206} \mathrm{~Pb} /{ }^{204} \mathrm{~Pb}$ isotope ratio $(\sim 200)$ or unreliable $\mathrm{U}-\mathrm{Pb}$ data (sample MC 6, not shown in Table III), which we attribute to high $\mathrm{Pb}$ blank of the microcapsule or to contamination during the analyses.

\section{RESULTS}

$\mathrm{U}-\mathrm{Pb}$ isotope analyses of nine zircon grains were determined by LA-MC-ICPMS and are shown in Table II.The data from eight zircon spots yielded a concordant age of $418.6 \pm 4.3 \mathrm{Ma}( \pm 1.02 \%)$ (Figure $1)$. The ${ }^{206} \mathrm{~Pb} /{ }^{238} \mathrm{U}$ age is $418.1 \pm 7.1 \mathrm{Ma}( \pm 1.7 \%$, $95 \%$ conf.). This result is in good agreement with the age published for Temora II zircon obtained by ID-TIMS and SHRIMP methods (Black et al. 2004), although the calculated error is too high for geochronological studies of Phanerozoic rocks.

In the present study, the dating by the ID-TIMS method is more appropriate for zircon grains with only one crystallization phase. Thus, the ID-TIMS analyses of the same zircon population of Temora II standard were performed in two important steps before the zircon dissolution, which permitted to get high quality results (Table III). Ultrapure water with very low total $\mathrm{Pb}$ blank was used, and this demanded a long time to obtain (approximately 4-6 months). Indeed, it is not possible to obtain a high resolution $\mathrm{U}-\mathrm{Pb}$ dating without a good laboratory blank (Bowring and Schmitz 2003).

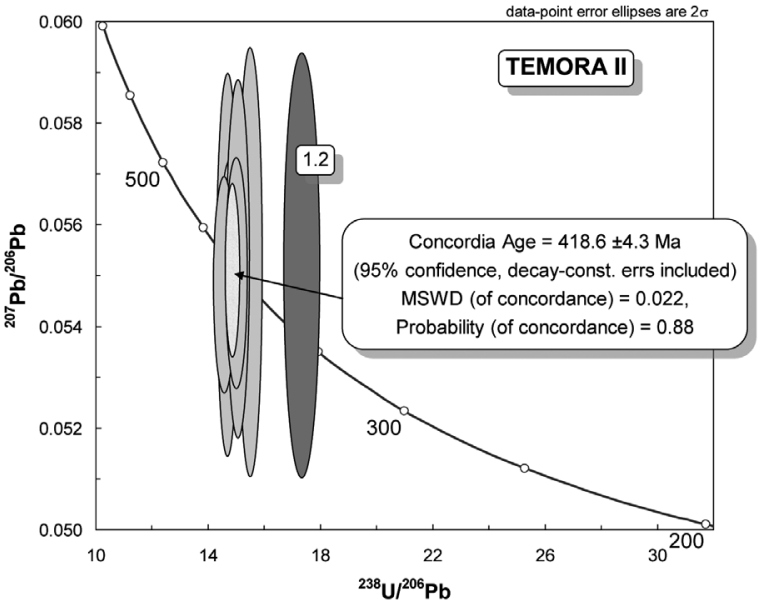

Figure 1 Takehara et al.

Figure 1. U-Pb concordia diagram for Temora II standard obtained by LA-MC-ICPMS.

Aother important step was the combination of zircon heating and chemical abrasion. This step showed that the results could be improved by leaching the common $\mathrm{Pb}$ present in the outer part of zircon grains. The heating procedure can seal small fractures, and, thus, homogenize the external surface, which was leached by chemical abrasion with HF vapor. The chemical abrasion procedure in this work is that described by Mundil et al. (2004).

The results are presented in Table III, which includes the analytical data of analyzed zircon grains and NBS 982 values obtained during the $\mathrm{U}-\mathrm{Pb}$ isotope analyses.

Two blanks and seven zircon samples were analyzed. The obtained values for blanks (microcapsules without samples) were $<1 \mathrm{pg} / \mathrm{g}$ of total $\mathrm{Pb}$. Two zircon samples presented either very low ${ }^{206} \mathrm{~Pb} /{ }^{204} \mathrm{~Pb}$ isotope ratios $(\sim 200)$ or unreliable $\mathrm{U}-\mathrm{Pb}$ data (sample $\mathrm{MC}$ 6), which we attribute to high $\mathrm{Pb}$ blank of the $\mathrm{MC}$ or to contamination during the analyses. From the five reliable analyses, two yielded concordant or almost concordant zircon fractions with concordia age at $416 \mathrm{Ma}$, and three discordant zircon fractions are used for age calculation (Figure 2). The age obtained is $415.7 \pm 1.8 \mathrm{Ma}( \pm 0.43 \%, 95 \%$ conf.) (Figure 3$)$, 
TABLE II

U-Pb in situ zircon data of Temora II standard obtained by LA-MC-ICPMS. Mean ${ }^{206} \mathrm{~Pb} /{ }^{238} \mathrm{U}$ age $=418.1 \pm 7.1[1.7 \%] 95 \%$ conf.

\begin{tabular}{|c|c|c|c|c|c|c|c|c|c|c|c|c|c|c|c|c|}
\hline \multirow[b]{2}{*}{$\begin{array}{c}\text { Grain } \\
\text { spot }\end{array}$} & \multirow[b]{2}{*}{ f 206} & \multicolumn{8}{|c|}{ Isotope ratios ${ }^{2,3}$} & \multicolumn{7}{|c|}{ Age (Ma) } \\
\hline & & $\begin{array}{c}{ }^{232} \mathbf{T} \mathbf{h}^{1 /} \\
{ }^{238} \mathbf{U}\end{array}$ & $\begin{array}{c}{ }^{207} \mathbf{P b}^{*} /{ }^{2} \\
{ }^{06} \mathbf{P b}^{*}\end{array}$ & err \% & $\begin{array}{c}{ }^{207} \mathbf{P b}^{*} /{ }^{35} \mathbf{U} \\
\end{array}$ & err \% & $\begin{array}{c}{ }^{206} \mathbf{P b}^{*} /{ }^{2} \\
{ }^{38} \mathbf{U}\end{array}$ & err \% & Rho $^{4}$ & $\begin{array}{c}{ }^{206} \mathbf{P b} /{ }^{2} \\
{ }^{38} \mathbf{U}\end{array}$ & \pm & $\begin{array}{c}{ }^{207} \mathbf{P b} /{ }^{2} \\
{ }^{35} \mathbf{U}\end{array}$ & \pm & $\begin{array}{c}{ }^{207} \mathrm{~Pb} /{ }^{2} \\
{ }^{06} \mathrm{~Pb}\end{array}$ & \pm & $\%$ Disc $^{5}$ \\
\hline 1.1 & 0.0006 & 0.25 & 0.0552 & 1.50 & 0.516 & 1.84 & 0.068 & 1.07 & 0.58 & 422 & 5 & 422 & 8 & 422 & 6 & 0 \\
\hline 1.2 & 0.0006 & 0.46 & 0.0552 & 3.11 & 0.439 & 3.45 & 0.058 & 1.48 & 0.43 & 362 & 5 & 370 & 13 & 420 & 13 & 14 \\
\hline 1.3 & 0.0010 & 0.20 & 0.0553 & 1.34 & 0.507 & 2.85 & 0.066 & 1.10 & 0.39 & 415 & 5 & 416 & 12 & 424 & 6 & 2 \\
\hline 1.4 & 0.0011 & 0.28 & 0.0552 & 1.70 & 0.492 & 3.33 & 0.065 & 1.12 & 0.34 & 404 & 5 & 406 & 14 & 422 & 7 & 4 \\
\hline 1.5 & 0.0005 & 0.37 & 0.0548 & 1.60 & 0.519 & 1.92 & 0.069 & 1.05 & 0.55 & 428 & 5 & 424 & 8 & 404 & 6 & -6 \\
\hline 1.5 & 0.0009 & 0.37 & 0.0550 & 1.69 & 0.506 & 2.01 & 0.067 & 1.08 & 0.54 & 416 & 5 & 416 & 8 & 413 & 7 & -1 \\
\hline 1.7 & 0.0004 & 0.28 & 0.0554 & 2.21 & 0.520 & 2.46 & 0.068 & 1.06 & 0.43 & 425 & 5 & 425 & 10 & 427 & 9 & 1 \\
\hline 1.8 & 0.0001 & 0.35 & 0.0552 & 2.80 & 0.519 & 3.00 & 0.068 & 1.06 & 0.35 & 425 & 5 & 424 & 13 & 420 & 12 & -1 \\
\hline 1.9 & 0.0006 & 0.42 & 0.0550 & 2.03 & 0.498 & 2.31 & 0.066 & 1.10 & 0.48 & 410 & 5 & 410 & 9 & 411 & 8 & 0 \\
\hline
\end{tabular}

1. ${ }^{232} \mathrm{Th} /{ }^{238} \mathrm{U}$ ratios are calculated relative to $\mathrm{GJ}-1$ reference zircon, where $\mathrm{Th} / \mathrm{U}={ }^{232} \mathrm{Th} /{ }^{238} \mathrm{U} * 0.992743$

2. Corrected for background and within-run $\mathrm{Pb} / \mathrm{U}$ fractionation and normalised to reference zircon $\mathrm{GJ}-1$

(ID-TIMS values/measured values); ${ }^{207} \mathrm{~Pb} /{ }^{235} \mathrm{U}$ calculated using $\left({ }^{207} \mathrm{~Pb} / 206 \mathrm{~Pb}\right) /\left({ }^{238} \mathrm{U} /{ }^{206} \mathrm{~Pb} * 1 / 137.88\right)$

3. Sample and standard are corrected after $\mathrm{Pb}$ and $\mathrm{Hg}$ blanks

4. Rho is the error correlation defined as the quotient of the propagated errors of the ${ }^{206} \mathrm{~Pb} /{ }^{238} \mathrm{U}$ and the ${ }^{207} / 235 \mathrm{U}$ ratio

5. Degree of disconcordance $=100 *\left(1-{ }^{206} \mathrm{~Pb} /{ }^{238} \mathrm{U}\right.$ age $/ 100 /{ }^{207} \mathrm{~Pb} / 206 \mathrm{U}$ age $)$

6. Light gray $=$ discordant (not used for concordia age)

TABLE III

(a) U-Pb zircon data of Temora II standard obtained by ID-TIMS; mean ${ }^{206} \mathrm{~Pb} /{ }^{238} \mathrm{U}$ age $=418.1 \pm 7.1[1.7 \%] 95 \%$ conf. and (b) Analytical data of NBS 982 values obtained during the $\mathrm{U}-\mathrm{Pb}$ analyses and NIST values.

\begin{tabular}{|c|c|c|c|c|c|c|c|c|c|c|c|c|c|c|c|c|c|c|c|}
\hline \multicolumn{5}{|l|}{ (a) } & \multicolumn{9}{|c|}{ Isotope ratios } & \multicolumn{6}{|c|}{ Age (Ma) } \\
\hline Sample & $\begin{array}{l}\text { Sample } \\
\text { Wt (mg) }\end{array}$ & $\begin{array}{c}\text { Spike } \\
\text { Wt (mg) }\end{array}$ & $\begin{array}{c}\mathrm{Pb} \\
\text { ppm }\end{array}$ & $\underset{\text { ppm }}{\mathrm{U}}$ & $\begin{array}{l}{ }^{206} \mathrm{~Pb} /{ }^{2} \\
{ }^{04} \mathrm{~Pb}\end{array}$ & $\begin{array}{c} \pm \\
(\%)\end{array}$ & 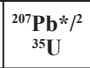 & $\begin{array}{c} \pm \\
(\%)\end{array}$ & $\begin{array}{c}{ }^{206} \mathrm{~Pb}^{* / 2} \\
{ }^{238} \mathbf{U}\end{array}$ & $\begin{array}{c} \pm \\
(\%)\end{array}$ & Rho & $\begin{array}{l}{ }^{207} \mathrm{~Pb}^{* / 2} / 2 \\
{ }^{00} \mathrm{~Pb}^{*}\end{array}$ & $\begin{array}{c} \pm \\
(\%)\end{array}$ & $\begin{array}{c}{ }^{206} \mathbf{P b} /{ }^{2} \\
{ }^{38} \mathbf{U}\end{array}$ & $\begin{array}{c} \pm \\
(\%)\end{array}$ & $\begin{array}{c}{ }^{207} \mathbf{P b} /{ }^{2} \\
{ }^{35} \mathbf{U}\end{array}$ & $\begin{array}{c} \pm \\
(\%)\end{array}$ & $\begin{array}{c}{ }^{207} \mathbf{P b} /{ }^{2} \\
{ }^{06} \mathbf{U}\end{array}$ & $\begin{array}{c} \pm \\
(\%)\end{array}$ \\
\hline TU MC 1 & 0.025 & 0.004 & 25 & 42 & 954 & 1.24 & 0.4437 & 0.95 & 0.0581 & 0.83 & 0.89 & 0.0554 & 0.42 & 364 & 3.0 & 373 & 3.5 & 427 & 1.8 \\
\hline TU MC 2 & 0.030 & 0.004 & 32 & 46 & 1975 & 0.38 & 0.4978 & 0.29 & 0.0655 & 0.28 & 0.96 & 0.0551 & 0.08 & 409 & 1.1 & 410 & 1.2 & 417 & 0.3 \\
\hline TU MC 3 & 0.020 & 0.004 & 37 & 60 & 920 & 0.62 & 0.4592 & 0.78 & 0.0604 & 0.74 & 0.95 & 0.0551 & 0.24 & 378 & 2.8 & 384 & 3.0 & 417 & 1.0 \\
\hline TU MC 7 & 0.015 & 0.008 & 75 & 100 & 1156 & 2.20 & 0.5034 & 0.79 & 0.0663 & 0.51 & 0.70 & 0.0551 & 0.57 & 414 & 2.1 & 414 & 3.3 & 416 & 2.4 \\
\hline TU MC 8 & 0.010 & 0.004 & 75 & 139 & 1432 & 3.58 & 0.4056 & 3.44 & 0.0529 & 3.35 & 0.98 & 0.0556 & 0.76 & 332 & 11 & 346 & 12 & 438 & 3.3 \\
\hline
\end{tabular}

1. Zircons are annealed/chemically abraded

2. Sample weight calculated from crystal dimensions

3. ${ }^{207} \mathrm{~Pb}^{*}$ and ${ }^{206} \mathrm{~Pb} *$ radiogenic $\mathrm{Pb}$

4. Estimated total $\mathrm{Pb}$ blank $=2 \mathrm{pg}$

(b)

\begin{tabular}{|c|c|c|c|c|c|c|c|c|c|c|}
\cline { 2 - 11 } \multicolumn{1}{c|}{} & ${ }^{206} \mathbf{P b} /{ }^{204} \mathbf{P b}$ & $\mathbf{2 \sigma}$ & ${ }^{207} \mathbf{P b} /{ }^{204} \mathbf{P b}$ & $\mathbf{2 \sigma}$ & ${ }^{208} \mathbf{P b} /{ }^{204} \mathbf{P b}$ & $\mathbf{2 \sigma}$ & ${ }^{207} \mathbf{P b}{ }^{206} \mathbf{P b}$ & $\mathbf{2 \sigma}$ & ${ }^{208} \mathbf{P b} /{ }^{206} \mathbf{P b}$ & $\mathbf{2 \sigma}$ \\
\hline $\begin{array}{c}\text { NBS 982 11.FEV.2008 } \\
\text { NIST }\end{array}$ & 36.726 & 0.031 & 17.138 & 0.032 & 36.665 & 0.033 & 0.4667 & 0.0084 & 0.9984 & 0.0118 \\
\hline $\begin{array}{c}\text { Correction due } \\
\text { fractionation }\end{array}$ & 36.744 & 0.050 & 17.159 & 0.025 & 36.738 & 0.037 & 0.4671 & 0.0002 & 1.0002 & 0.0004 \\
\hline
\end{tabular}

* During the month (February) we analysed repeatedely the NBS-981 and NBS-982, and the Pb fractionation of amu $=$ or $<0.1 \%$ 
which is very close to the accepted TIMS age for the Temora I (416.75 $\pm 1.3 \mathrm{Ma}$, Black et al. 2003) and Temora II (416.78 $\pm 0.33 \mathrm{Ma}$, Black et al. 2004).
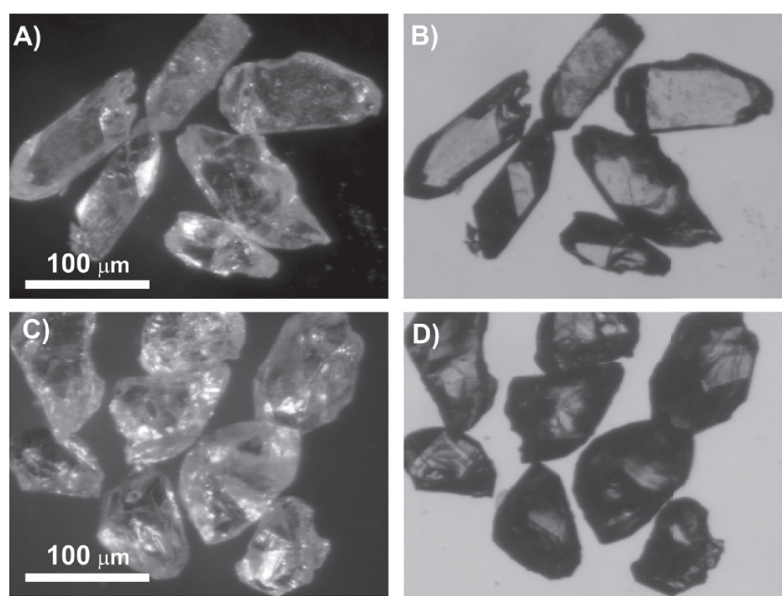

Figure 2. Photomicrography of analyzed zircon grains in transmitted $(\mathrm{A}, \mathrm{C})$ and reflected light $(\mathrm{B}, \mathrm{D})$, where $\mathrm{A}$ and $\mathrm{B}$ are long prismatic, and $\mathrm{C}$ and $\mathrm{D}$ short prismatic crystals.

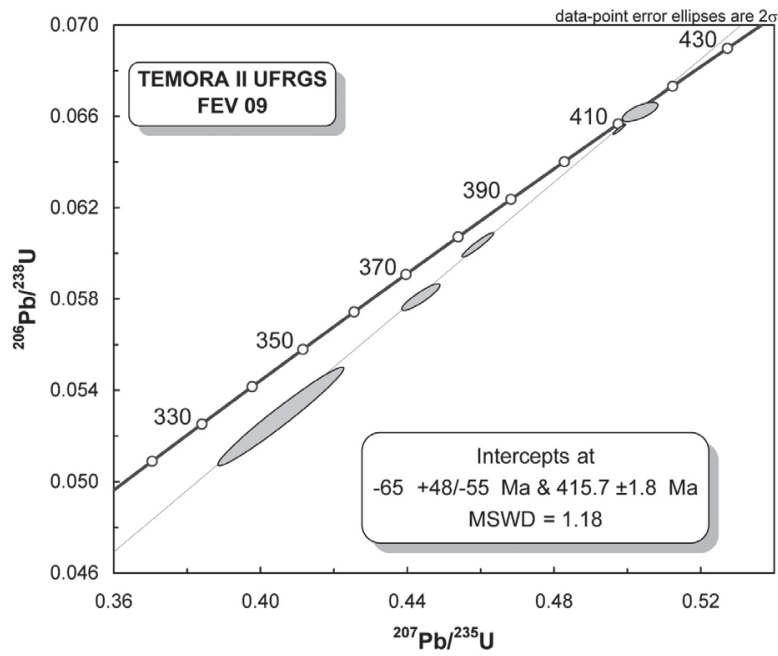

Figure 3. U-Pb concordia diagram for Temora II standard obtained by ID-TIMS.

\section{CONCLUSIONS}

Zircon analyses for in situ dating by the LA-MCICPMS or SHRIMP method can be appropriate for choosing single zircon grains to be used for high resolution dating by the ID-TIMS method.

The analytical results obtained here by the LA-MC-ICPMS method have a great advantage because this is a quick analytical method (usually one day), although the error uncertainty is larger than $1 \%$. The obtained age and error can be used for regional geological studies or detrital zircon age determination, but it cannot solve some questions such as high resolution stratigraphic studies of Phanerozoic sequences.

On the other hand, the ID-TIMS method is a time consuming method as it takes at least seven days to be performed, and is very sensitive to laboratory conditions. The obtained age and error are more precise and accurate, with an error uncertainty $<0.5 \%$, so the method can be applied to high resolution, Phanerozoic stratigraphy. The results of the present study, with the ID-TIMS methods combined with a previous in situ zircon dating, i.e., LA-MC-ICPMS method, are therefore significant for $\mathrm{U}-\mathrm{Pb}$ high precision analyses, because the total $\mathrm{Pb}$ blank of the laboratory is under $2 \mathrm{pg} / \mathrm{g}$, and the dated zircon phase has a single crystallization phase. The chemical abrasion combined with step heating is also a recommended method since it considerably decreases the amount of common $\mathrm{Pb}$ in zircon grains before their dissolution.

\section{ACKNOWLEDGMENTS}

The authors would like to thank Coordenação de Aperfeiçoamento de Pessoal de Nível Superior (CAPES) for supporting the first author with a scholarship of Programa Nacional de Pós-Doutorado (PNPD) during this study. We thank Chris Foudoulis of the Geological Survey of Australia for providing Temora II sample and Márcio M. Pimentel for the $\mathrm{U}^{235}-\mathrm{Pb}^{205}$ combined spike.

\section{RESUMO}

Este trabalho apresenta a técnica de abrasão química em zircões do padrão Temora II aplicada em datação de U-Pb por Dissolução Isotópica e Espectrometria de Massa por Ionização Térmica, método DI-ESIT. O emprego deste método tem como princípio diminuir os efeitos da 
perda secundária de $\mathrm{Pb}$ radiogênico antes da dissolução. Em primeira instância, os zircões foram analisados pelo método in situ com uso de Microssonda Laser acoplada a um Espectrômetro de Massa Multicoletor com Plasma Acoplado Indutivamente (MC-ICP-MS), cujo objetivo foi identificar os grãos de zircão de fase de cristalização simples sem sobrecrescimento. Nove cristais de zircão analisados com microssonda a laser forneceram uma idade

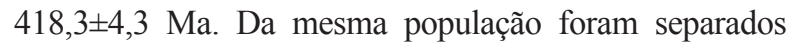
cristais de zircão para datação utilizando a técnica de abrasão química e posterior análise pelo método DI-ESIT. Seis amostras de zircão foram separadas para diluição isotópica com adição de um traçador isotópico combinado $\mathrm{U}^{235}-\mathrm{Pb}^{205}$, em condições laboratoriais de brancos analíticos de $\mathrm{Pb}$ total menor que $2 \mathrm{pg} / \mathrm{g}$. A idade U-Pb em

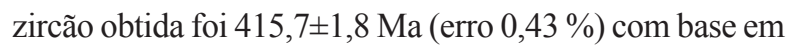
cinco amostras de zircão. Os resultados são concordantes com aquelas idades publicadas para o diorito Temora (Temora I-416,75 $\pm 1,3 \mathrm{Ma}$; Temora II - 416,78 $\pm 0,33 \mathrm{Ma}$ ). A técnica descrita aqui é, portanto recomendada para ser aplicada em análises isotópicas de U-Pb com alta precisão (erros menor que 1\%) para estudos de estratigrafia de alta resolução de sequências fanerozóicas.

Palavras-chave: abrasão química, ID-TIMS, LA-MCICPMS, datação U-Pb, dissolução de zircão.

\section{REFERENCES}

Black LP, Kamo SL, ALlen CM, AleinikofF JN, DaVis DW, KORSCH RJ AND FOUDOULIS C. 2003. TEMORA 1: a new zircon standard for Phanerozoic U-Pb geochronology. Chem Geol 200: 155-173.
BLACK LP ET AL. 2004. Improved ${ }^{206} \mathrm{~Pb} / 238 \mathrm{U}$ microprobe geochronology by the monitoring of a trace-elementrelated matrix effect; SHRIMP, ID-TIMS, ELA-ICP-MS and oxygen isotope documentation for a series of zircon standards. Chem Geol 205: 115-140.

BOWRING SA AND SCHMITZ MD. 2003. High precision zircon geochronology and the stratigraphic record. In: Hanchar JM and Hoskins PWO. Zircon: Experiments, Isotopes, and Trace Element Investigations. Rev Mineral Geochem 53: 305-326.

Chemale Jr F, Kawashita K, Dussin IA, Ávila JN, Justino D AND BERTOTTI AL. 2012. U-Pb zircon in situ dating with LA-MC-ICP-MS using a mixed detector configuration. An Acad Bras Cienc 84: 275-295.

JACKSON S, PEARSON NJ, GRIFFIN WL AND BELOUSOVA EA. 2004. The application of laser ablation-inductively coupled plasma-mass spectrometry to in situ $\mathrm{U}-\mathrm{Pb}$ zircon geochronology. Chem Geol 211: 47-69.

Kosler J, Tubrett M AND Sylvester P. 2001. Application of Laser Ablation ICP-MS to U-Th-Pb Dating of Monazite. Geostandards Newsletter 25(2): 375-386.

LUDWIG KR. 2003. User's manual for Isoplot 3.00 Berkeley Geochonology Centre, Berkeley.

Mundil R, Ludwig KR, Metcalfe I And Renne PR. 2004. Age and timing of the Permian mass extinctions: U/ $\mathrm{Pb}$ dating of closed-system zircons. Science 305(5691): 1760-1763.

Pickhardt C, Dietze H-J AND BeCKer JHS. 2005. Laser ablation inductively coupled plasma mass spectrometry for direct isotope ratio measurements on solid samples. Int J Mass Spectrom 242: 273-280.

RASMUSSEN B. 2005. Radiometric dating of sedimentary rocks: application of diagenetic xenotime geochronology. Earth Sci Rev 68: 197-243.

Simon E, JaCKson SE, PeArsona NJ, GrifFina WL AND Belousova EA. 2004. The application of laser ablationinductively coupled plasma-mass spectrometry to in situ U-Pb zircon geochronology. Chem Geol 211: 47-69.

WILLIAMS IS. 1998. U-Th-Pb geochronology by ion microprobe. In: McKibben MA, Shanks III WC and Ridley WI (Eds), Applications of Microanalytical Techniques to Understanding Mineralization Processes. Rev Econ Geol SEG, E1 Paso, Texas 7: 1-75. 